Int. J. Speleol. 14 (1984-1985); pp. 69-85

\title{
The anatomy and histology of the alimentary tract of the blind catfish Horaglanis Krishnai Menon
}

\author{
T.V. Anna Mercy* \& N. Krishna Pillai**
}

SUMMARY

H. krishnai is a blind catfish inhabiting the dug-out wells at Kottavam Kerala, South India. Studies on the alimentary tract of the fish show that, the alimentary tract, though typically teleostean, shows several adaptive modifications. The bulbous stomach helps in storing food which is helpful in an environment chronically deficient in food. The ileo-rectal sphincter helps in retaining the digested food in the intestine for a long duration to facilitate maximum absorption. This is very helpful as the intestine is short. The liver is well developed.

The digestive system of teleosts has been studied extensively both in India and abroad. The first half of the twentieth century witnessed a spurt in the study of the alimentary canal, especially in relation to feeding habits. The histology of the digestive tract of several freshwater fishes was studied in India (Dharmarajan, 1936; Vanajakshi, 1938; Mohsin, 1941, 1946, 1962; Mahadevan, 1950; Sarbahi, 1951; Kapoor, 1953; Moitra and Bowmik, 1967; Lal, 1968; Mehrotra and Khanna, 1969; Moitra and Sinha 1971, 1972; Sinha and Moitra 1972, 1975, 1976; Thomas, 1975 and Moitra and Ray 1977). Though the above resume indicates the availability of a considerable amount of literature on the subject, none of them deal with a blind catfish.

The alimentary canal of all teleosts is built on the same fundamental plan. But studies undertaken so far have shown

* Fisheries College, Panangad, Cochin 682 506, India.

** Department of Aquatic Biology and Fisheries, University of Kerala, Trivandrum 695 007, India. 
that within the fundamental plan there is considerable variation in details depending on the difference in feeding habits.

Horaglanis krishnai is a blind clariid inhabiting the dug-out wells at Kottayam, Kerala, South India. It has a very unusual habitat in freshwater wells to which they gain entry through the subsoil drainage system. Moreover, this fish is totally blind. These two factors are bound to make the fish a specialized feeder.

\section{MATERIAL AND METHODS}

Specimens of Horaglanis were collected from the dug-out wells at Kottayam (Latitude $8^{\circ} 4{ }^{\prime} \mathrm{N}$ and $10^{\circ} 21^{\prime} \mathrm{N}$; Longitude $76^{\circ} 13^{\prime} \mathrm{E}$ and $77^{\circ} 38^{\prime} \mathrm{E}$ ), Kerala, South India, by draining them. Fishes were brought to the laboratory in alive condition and the alimentary canal is dissected out and fixed in Bouin's fluid. Serial sections were taken at 6-8 $\mu$ thickness and stained in Harry's Haematoxylin, counterstained with eosin.

\section{MORPHOLOGY}

\section{General course of the alimentary canal}

The alimentary canal of Horaglanis krishnai includes a spacious buccopharyngeal cavity, a straight oesophagus, a bulbous stomach and a straight intestine which opens out through the anus (Fig. 1).

The oral aperture is wide, crescentic and slightly upturned, spanning the entire width of the snout. It is surrounded by four pairs of barbels. Both jaws are armed with a patch of several irregular rows of villiform teeth curving inwards (Figs. 2 \& 4). From the inner margin of both jaws extends, into the buccal cavity for a short distance, a fold of membrane - the buccal membrane. This membrane is crescentic in shape and that of the upper jaw is called the maxillary and that of the lower the mandibular valve. On the floor of the buccal cavity is a muscolar prominence comparable to the tongue of higher vertebrates. The tongue is roughly club-shaped and is slightly concave dorsomedially. The buccal cavity is roughly equal in length and width.

As the pharynx is not clearly demarcated from the buccal cavity, $H$. krishnai has only a buccopharyngeal cavity. However, 


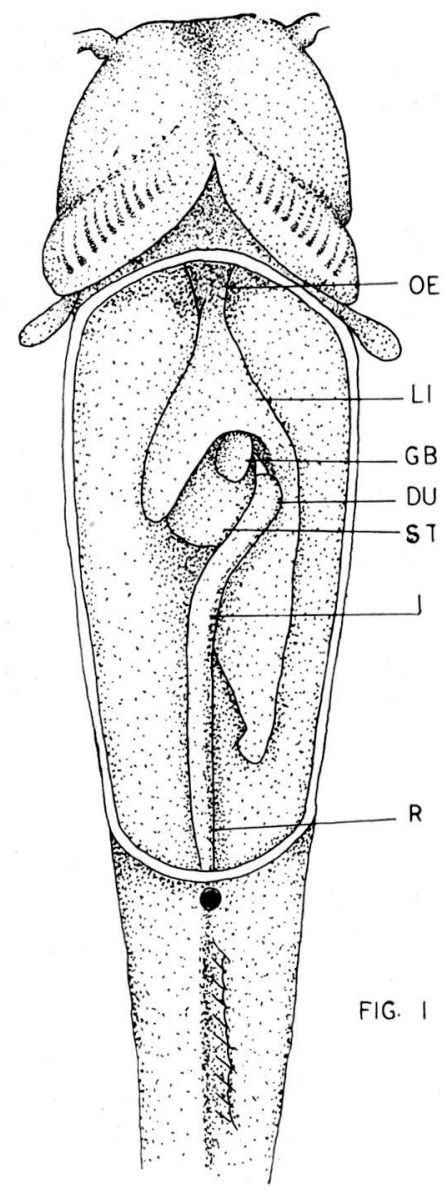

Fig. 1 - Visceral cavity showing the digestive system (diagrammatic). OE, oesophagus; LI, liver; GB, gall bladder; DU, duodenum; ST, stomach, I, intestine; $R$, rectum.

for descriptive purposes the first pair of gill slits is considered as forming the boundary demarcating these two regions. The pharyngeal chamber is perforated by four pairs of ventrolateral gill slits. The pharynx gradually narrows backwards and consists of an anterior and a posterior region, the former carrying the gill slits. The gill arches are provided with blunt gill rackers. The posterior part of the pharynx is narrow and imperceptibly merges with the oesophagus. 


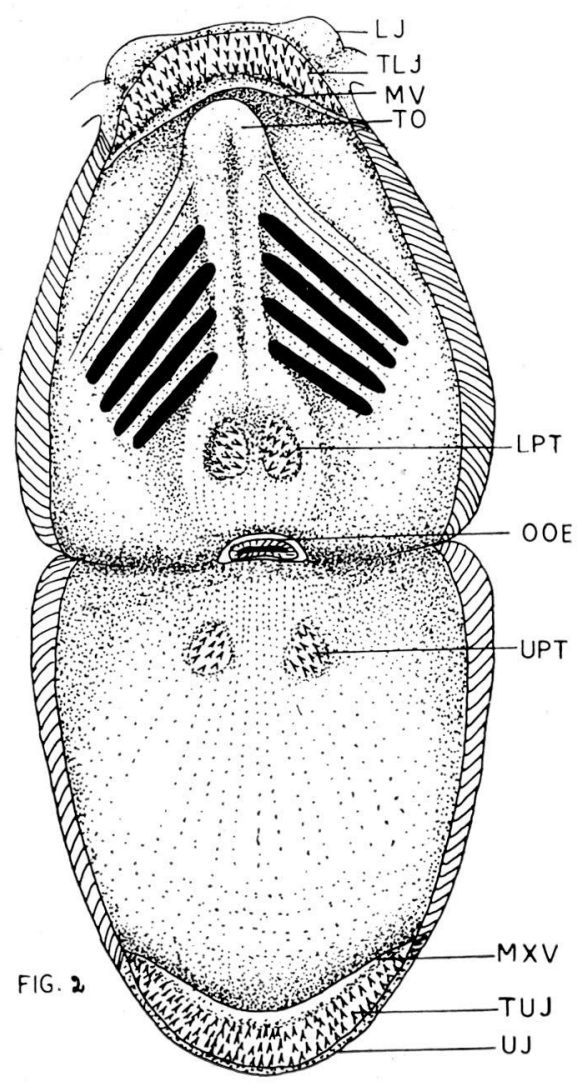

Fig. 2 - Buccal cavity (diagrammatic). LJ, lower jaw; TLJ, teeth on lower jaw; MV, mandibular valve; TO, tongue; LPT, lower pharyngeal teeth; OOE, opening to oesophagus; UPT, upper pharyngeal teeth; MXV, maxillary valve; TUJ, teeth on the upper jaw; UJ, upper jaw.

The posterior part of the pharyngeal chamber has a pair of dorsomedian patches of villiform teeth. Placed on the floor of the pharynx are two triangular patches of villiform teeth corresponding to those on the roof.

The oesophagus is a straight tube of uniform diameter. It enters the stomach which appears as a mere bulbous expansion of the hind part of the oesophagus. The anterior part of the stomach is thin-walled and the posterior thick-walled. These two represent the cardiac and pyloric portions respectively. 
The stomach is followed by the intestine, which, on emerging from the stomach, goes forwards up to the middle of the stomach and then backwards forming a duodenal loop. This loop has a larger diameter than the intestine proper. The bile duct enters at the junction of the pyloric stomach with the duoand there is apparently no well-marked rectum. In a fish $3 \mathrm{~cm}$ denal loop. The intestine goes straight up to the anal opening long, the different regions of the alimentary canal had the following measurements. From the lips to the level of the first gill arch $-2 \mathrm{~mm}$, from the lips to the beginning of the oesophagus - $3.5 \mathrm{~mm}$, beginning of the oesophagus to the stomach $-4 \mathrm{~mm}$, stomach - $2 \mathrm{~mm}$, intestine $-7 \mathrm{~mm}$.

\section{Associated organs}

\section{Liver}

The liver of $H$. krishnai is large, extending over two thirds the length of the body cavity (Figs. $1 \& 3$ ). It consists of an an-

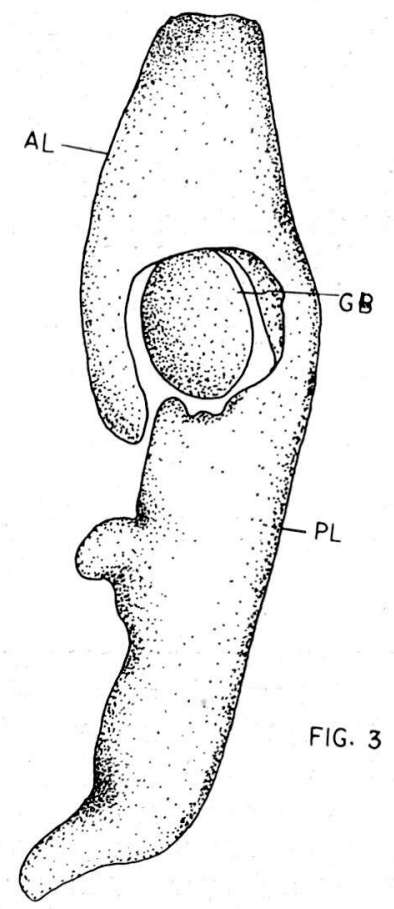

Fig. 3 - Liver. AL, anterior lobe; GB, gall bladder; PL, posterior lobe. 
terior and a posterior lobe connected by a median narrow portion. The anterior lobe is roughly triangular and covers the oesophagus and part of the stomach. The left side of this lobe is continued as the posterior lobe. This lobe lies close to the intestine.

\section{Gall-bladder}

The gall-bladder is sac-like and lies near the stomach. The bile duct opens into the anterior end of the duodenum.

\section{HISTOLOGY}

\section{Lips}

The lips are made up of the mucosa and submucosa. The mucosa consists of a stratified epithelium and a basement membrane. The epithelium is formed of 8-12 rows of hexagonal cells with rounded centrally placed nuclei. Scattered amidst the epithelial cells are large round or oval mucous cells with eccentrically placed deeply staining nuclei. A number of taste buds, placed on papillalike extensions of the submucosa, are scattered in the mucosa. The taste buds are composed of elongated epithelial cells with deeply staining oval nuclei placed near the base of the cells. The taste buds comunicate to the outside by means of an opening through which project hair-like extensions of the cells of the taste bud. brane

The stratified epithelium rests on a thin basement mem-

The submucosa is a compact layer composed of connective tissue fibres, blood vessels and nerve fibres.

\section{Buccal membrane}

The buccal membrane consists of mucosa, submucosa, muscularis and adipose tissue. The mucosa is formed of stratified epithelium and basement membrane. The stratified epithelium consists of 5-6 rows of hexagonal cells with rounded centrally placed nuclei. Oval or rounded mucous cells are found scattered in the epithelium. The mucous cells have deeply staining eccentrically placed nuclei, and are more abundant on the buccal membrane than on the lips.

The stratified epithelium rests on a thin basement membrane. This is followed by the submucosa which is made up of a 
dense layer of connective tissue fibres. The submucosa is followed by the muscularis, which includes an inner layer of longitudinal and an outer layer of circular muscle. All the muscle fibres are of the striated type. The muscularis on the roof of the buccal cavity is very thin but is comparatively thick on the floor. It is thickest on the tongue. The muscularis is enveloped by adipose tissue which consists of 4-5 layers of vesicular cells which are round or oval in shape. The space inside the vesicular cells is mostly filled with fat and a very small quantity of protoplasm. Both on the roof and on the floor of the buccal mucosa there are cnly very few taste buds. But on the tongue there is a concentration of the taste buds (Fig. 5). These taste buds do not in any way differ from those on the lips.

The maxillary and mandibular valves also are made up of two layers of mucosa enclosing a layer of submucosa. In the maxillary valve, the ventral layer of the mucosa is thicker and in the mandibular valve the dorsal layer is thicker. The mucosa is composed of the same layers as those on the lips. The dorsal mucosa of the mandibular valve has a large number of taste buds and mucous cells while the ventral mucosa of the maxillary valve has only a few.

\section{Pharynx}

The pharyngeal mucosa is thrown up into longitudinal folds which progressively increase in height backwards. The pharyngeal wall consists of mucosa, submucosa and muscularis.

The mucosa is formed of stratified epithelium and basement membrane. The epithelium is made up of 8-10 layers of hexagonal cells in the anterior region and 12-14 layers in the posterior. Among the epithelial cells, round or oval mucous cells with eccentrically placed deeply staining nuclei are present. The mucous cells are more abundant in the posterior region. At certain places the mucosa consists almost entirely of mucous cells. Taste buds are not found in the pharyngeal mucosa.

The stratified epithelium rests on a thin basement membrane. The basement membrane is followed by a thick submucosa.

The topmost part of the submucosa is made up of a dense layer of connective tissue fibres which is thrown into papillalike extensions projecting into the mucosa.

The submucosa is followed by a layer of longitudinal muscle fibres. The longitudinal muscle layer is followed by a thick layer of circular muscle fibres. Both are striated. The patches of teeth on the roof and floor of the mouth are composed of villiform teeth in different stages of growth (Fig. 6). 

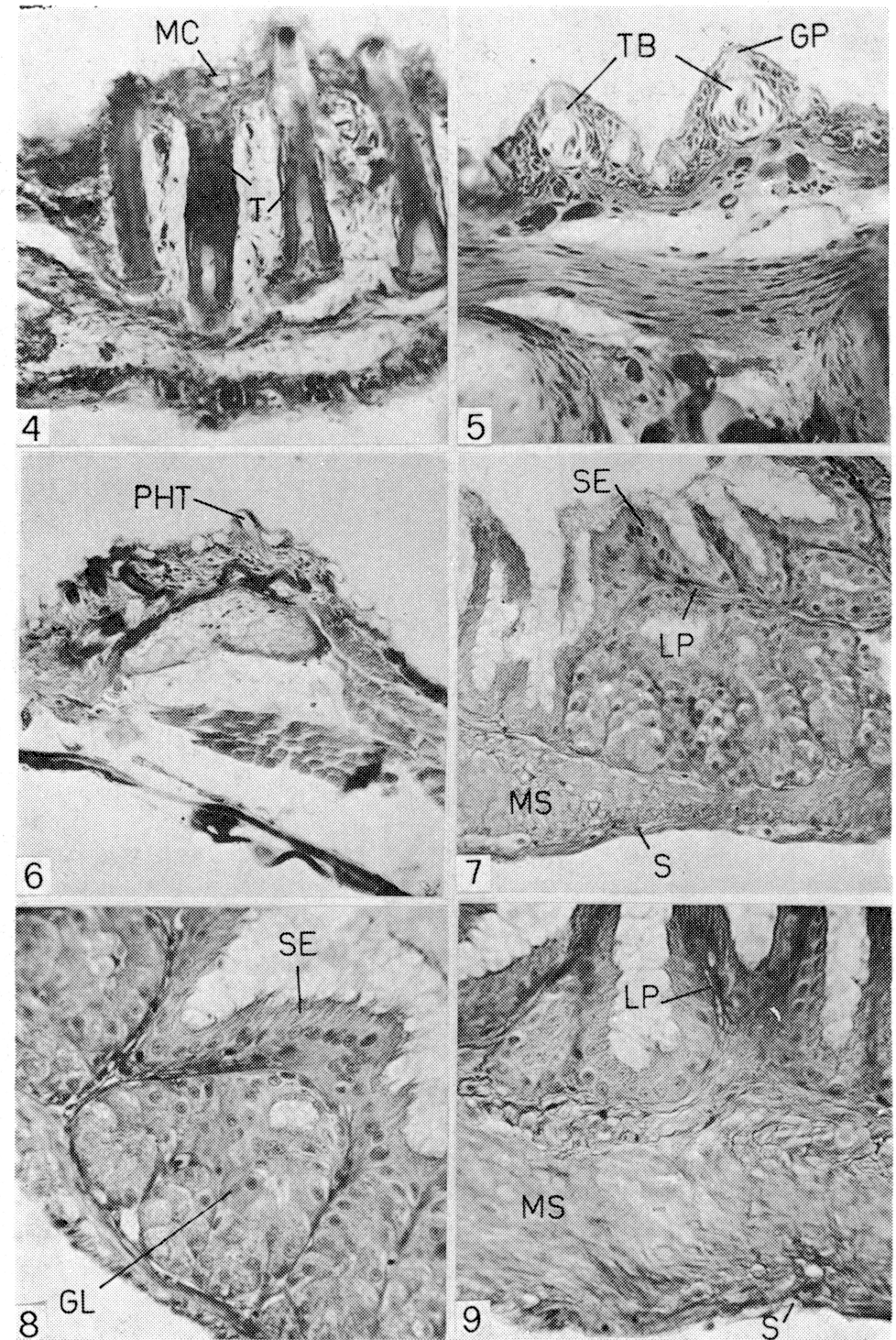

Figs 4-9 - Cross sections of: jaw (fig. 4, x 200), tongue (fig. 5, x 200), pharynx (fig. 6, x 60), cardiac stomach (fig. 7, x 60), stomach wall (fig. 8, x 60), pyloric stomach (fig. 9, x 200). MC, mucous cells; T. villiform teeth; GP, gustatory pore; TB, taste bud; PHT, pharyngeal teeth; SE, striated epithelium; LP, lamina propria; MS, muscularis; S, serosa; GL, gland. 


\section{Oesophagus}

The oesophageal wall is formed of mucosa, lamina propria, submucosa, muscularis and serosa. The mucosa is thrown up into several longitudinal folds. These folds are low in front but progressively increase in height backwards. In the anterior region the mucosa consists of columnar epithelial cells and a large number of oval, round and elongated mucous ccells. In some of the folds the mucous cells form a nearly continuous layer almost fully covering the columnar epithelial cells. In the columnar cells the nuclei are rounded and basal. The nuclei of the mucous cells are rounded, deeply staining and eccentric in position.

At the posterior region of the oesophagus the mucous cells are comparatively few and the mucosa is formed almost entirely of columnar cells. The cell margin has a serrated appearance. This is particularly evident in the cells situated on the summit of the folds. The nuclei of the columnar cells are oval and either central or basal in position. Each has a centrally located nucleolus. The cytoplasm of the columnar cells is homogeneous and eosinophilic. The epithelial cells rest on a thin basement membrane. This is followed by the lamina propria.

At either end of the oesophagus, the lamina propria is composed of compactly arranged connective tissue fibres with blood capillaries and free lymphatic cells.

The lamina propria is followed by a thin submucosa which is a dense layer of connective tissue fibres, also containing blood capillaries and nerve fibres.

The next layer is the muscularis which includes striated longitudinal and circular muscle fibres. The muscularis is enveloped by the serosa which is made up of highly flattened cells and tough connective tissue fibres.

At the junction of the oesophagus and the cardiac stomach the height of the mucosal folds increases. Here the mucosa contains only very few mucous cells. The folds show branching and the cells lining them have striated free margins. Secondary folds appear between the primary ones.

\section{Stomach}

Histologically, the stomach is divisible into cardiac and pyloric portions. The wall of the cardiac region is made up of mucosa, lamina propria, submucosa, muscularis and serosa (Fig. 7).

The mucosa is produced into branching folds, the free border of which shows serrated appearance. The mucosa consists of a compact superficial layer of columnar cells and an inner 
layer of glandular cells. The villi are entirely formed of columnar cells. The nuclei of the columnar cells are oval and basal in position. The columnar cells rest on a basement membrane which is followed by the lamina propria - a compact layer of connective tissue fibres. It contains blood vessels and lymphatic cells.

Rectangular glandular cells arranged in the form of simple tubular glands are seen in large numbers below the villi. These glands are kept in position by the connective tissue fibres of the lamina propria. Each gland has a narrow duct opening into the crypts. The cytoplasm of the cells forming the glands is granular and contains zymogen granules. Their nuclei are rounded, deeply staining and central in position (Fig. 8).

The glandular epithelium is followed by the submucosa which is a compact layer of connective tissue fibres. This is followed by the muscularis which is composed of an inner layer of circular muscle fibres and an outer layer of longitudinal muscles, both non-striated.

The muscularis is followed by the serosa, composed of highly flattened cells and fibrous connective tissue.

Barring the absence of the glandular epithelium, the wall of the pyloric stomach is histologically identical to that of the cardiac (Fig. 9). The mucosa is produced into longitudinal villi whose branches are fewer and shorter compared to those of the cardiac stomach. The mucosa consists of only columnar epithelial cells with oval basally placed nuclei. The free surface of the villi is serrated. The epithelial cells rest on a thin basement membrane.

The lamina propria consists of compactly arranged connective tissue fibres, blood vessels and lymphatic cells.

The submucosa is also a compact layer of connective tissue fibres and containes blood vessels and nerve fibres. The muscularis is very thick, compared to that of the cardiac region, and consists of a thick inner layer of circular muscle fibres and a thin outer layer of longitudinal fibres, both non-striated. The muscularis is especially thick at the posterior part of the pyloric stomach. This thick layer apparently acts as the pyloric sphincter. The muscularis is followed by the serosa consisting of flattened epithelial cells and fibrous connective tissue.

\section{Intestine}

The stomach is followed by the intestine which is divisible into duodenum, intestine proper and rectum. These three regions, though with very minor differences, are histologically identical.

The intestinal wall is formed of the mucosa, lamina propria, 
submucosa, muscularis and serosa. The number of villi in the duodenum varies from 10-12. Some of them are very broad while a few are narrow. Most of them are branched. The mucosa consists of elongated columnar cells and oval, rounded or elongated mucous cells; the elongated ones predominating. The nuclei of the columnar cells are oval and basally located with prominent nucleoli. The nuclei of the mucous cells take deep stain and are mostly concentrically placed. But in some of the round mucous cells the nuclei are central. The epithelial cells rest on a thin basement membrane. This is followed by the lamina propria.

The lamina propria is a compact layer of connective tissue fibres containing blood vessels and free lymphatic cells.

The lamina propria is followed by a thin submucosa formed of a dense layer of connective tissue fibres. This is followed by the muscularis composed of an inner circular and an outer longitudinal layer of muscle fibres. The muscularis is surrounded by a thin serosa formed of flattened epithelial cells and a few connective tissue fibres.

The intestine proper differs from the duodenal part in the number of the villi, which is only 5-6, in the very broad lamina propria in some of the villi, and in the presence of a large number of mucous cells (Fig. 10).

Towards the posterior region, the rectum telescops into the intestine. At the junction of these two the submucosa and the muscularis of both intestine and rectum are appreciably thick giving rise to an ileo-rectal valve (Fig. 11).

In the rectal region the villi are very short. The mucosa consists of columnar epithelial cells and rounded mucous cells. The nuclei of the epithelial cells are round or oval and basal in position; those of the mucous cells are round, deeply staining and centrally or eccentrically placed. The epithelium rests on a basement membrane which is fcllowed by the lamina propria (Fig. 12).

In the rectal region it is difficult to distinguish the lamina propria from the submucosa. The only difference between these two is the absence of longitudinal muscle bundles in the lamina propria. The lamina propria consists of loosely arranged connective tissue fibres and blood capillaries. The submucosa is very thick and is formed of loosely packed connective tissue fibres and blood capillaries. Among the connective tissue fibres there are longitudinal muscle fibres. Nerve fibres are also present. The submucosa is followed by a thin layer of circular muscle fibres and compactly arranged longitudinal muscle fibres forming the muscularis.

The muscularis is enveloped by a thick serosa formed of tough connective tissue fibres and flattened cells. 


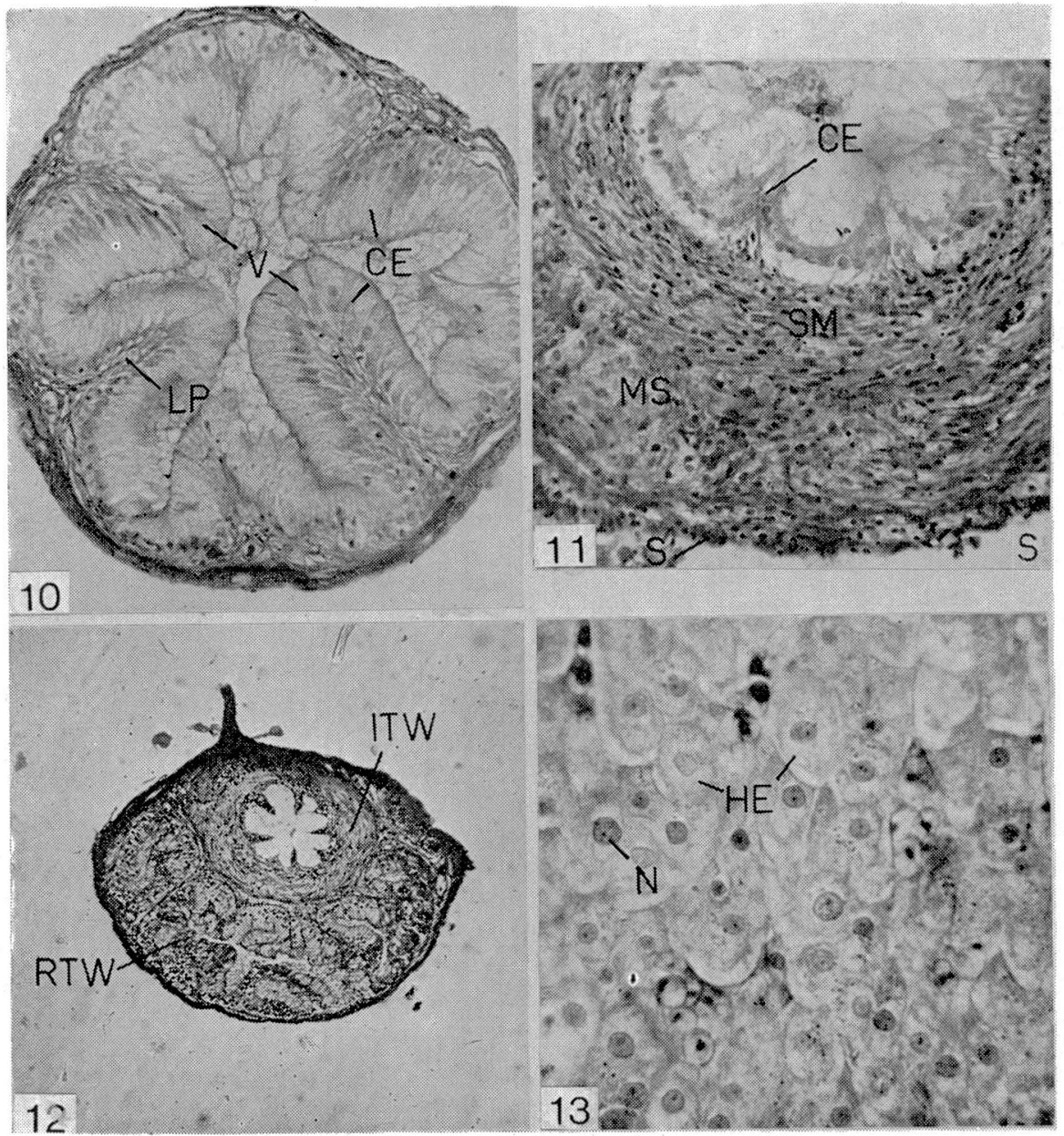

Figs. 10-13 Cross sections of: middle intestine (fig. 10, $x$ 51), rectum (fig. $11, \times 230$ ), rectum (fig. 12, x 51), liver (fig. 13, x 307). CE, columnar cells; V, villi; LP, lamina propria; SM, submucosa; MS, muscularis; S, serosa; ITW, intestinal wall; RTW, rectal wall; $\mathrm{HE}$, hepatic cells; $\mathrm{N}$, nucleus.

\section{Liver}

The liver is made up of regularly arranged polygonal hepatic cells. Each cell possesses a fairly large, centrally placed, rounded nucleus with distinct nucleolus. The cells are regu- 
larly arranged around the hepatic ductules. The capillaries called hepatic sinusoids are irregular and thin walled. The sinusoids anastomose and converge to join the large veins. The hepatic cells are vacuolated, with highly granular cytoplasm (Fig. 13).

\section{Gall bladder}

The wall of the gall bladder is thin and it consists of an inner layer of simple squamous epithelial cells, a middle layer of connective tissue and an outer layer of muscular tissue.

\section{DISCUSSION}

Teleosts have successfully adapted themselves to every type of aquatic habitat. This versatility is reflected in their mode of feeding. Fishes inhabiting the same habitat resort to different types of feeding to avoid competition for food and also to utilize every available source of food. They can be broadly classified into carnivores, herbivores and omnivores. It is only natural that depending on the kind of food the alimentary canal should undergo suitable modifications for maximum utilisation of the food taken.

The morphology and histology of the alimentary canal of $H$. krishnai show several peculiarities which can be correlated with its feeding behaviour.

As the lower jaw is slightly longer than the upper, the oral aperture is subdorsal. Obviously, this fish is not a true bottom feeder. As the gut content of the fish showed the presence of insects, it is evident that the fish can catch small animals like insects moving in its vicinity.

One of the organs of the alimentary system which shows adaptive modification to a large extent is the tooth. Presence of teeth on both the jaws indicates a carnivorous habit. In $H$. krishnai the pharyngeal teeth are also well developed. It would appear that the pharyngeal teeth help to crush the food organisms and the curved villiform jaw teeth serve to prevent the prey from escaping. Sarbahi (1939), Al-Hussaini (1946) and Das and Moitra (1955) have observed that the pharyngeal teeth are mainly used to crush the food.

The stomach is reported to be absent in fishes of the families Blennidae, Callyonimidae, Labridae and Scaridae. In catfishes it is fairly well developed. H. krishnai has a bulbous stomach. It should be remembered in this context that the fish is blind and capturing live food should be accomplished with the 
help of senses other than vision. Moreover, in the underground channels or in wells food is very scarce. Hence, for sheer survival, $H$. krishnai should be able to make full use of every opportunity to feed. This would explain the presence of a comparatively large bulbous stomach which helps to store the food. Though somewhat far fetched it should be pointed out that blind or partially blind deep sea fishes have a disproportionately large and highly distensible stomach which is definitely an adaptation to survive in the deep-sea where food is indeed scarce.

The intestine of H. krishnai is short. Jacobshajen (1913) found a direct correlation between the nature of the food and the length of the intestine. According to him, carnivorous fishes have short intestines and plant and mud feeders have long intestines. Though Suyehiro (1942) mentioned some exceptions to this generalisation one must admit that it generally holds good. Barrington (1957) suggested that the length of the intestine is dependent on more than one factor. Sinha and Moitra (1975) found that the nature of the food ingested by a fish largely determines the length of the gut and the number and nature of the mucosal folds. The short intestine of $H$. krishnai appears to indicate that this fish is a carnivore.

Histological variations in the alimentary tract are confined to the mucosa. The mucosa shows a fair amount of variation from the buccal cavity right up to the rectum. The most variable feature is the abundance and distribution of the mucous cells and taste buds.

Several workers (Vanajakshi, 1938; Girgis, 1952; Mookerjee and Ganguly, 1952; Kapoor, 1957; Pasha, 1964; Chitray, 1965 and Agarwal and Sharma 1966) have reported the presence of taste buds on the lips of fishes. In $H$. krishnai taste buds are of considerable value in gustation. In $H$. krishnai taste buds are present on the lips. Hence it is safe to assume that this fish is definitely a taste feeder. The presence of taste buds in the buccal cavity of fishes has been observed by several authors (Pillai, 1953; Mohsin, 1962; Chitray, 1965 and Moitra and Bhowmik, 1967). In H. krishnai though taste buds are few on the wall of the buccal cavity, they are abundant on the tongue. The tongue controls the entry of food into the oesophagus. So it is probable that the taste buds enable the fish to select desirable items and reject undesirable ones.

The presence of mucous cells on the lips and in the buccopharyngeal region has been reported in the above mentioned publications. In $H$. krishnai mucous cells are abundant in the wall of the pharynx. It seems that during feeding the pharynx produces a large amount of mucus which would undoubtedly help in swallowing the food probably in the form of bolus. As the fish feeds mainly on insects it may need a lot of mucus for lubrication. 
The mucosa of the cardiac region has a glandular epithelium arranged in the form of simple tubular glands and the mucosa of the pyloric region is devoid of a glandular epithelium. But the pyloric region is provided with a pyloric sphincter. The serrated margin of the epithelial cells of the villi is simply a device to increase the surface area for absorption of the digested food. The pyloric sphincter helps in regulating the passage of food into the intestine.

The intestine of $H$. krishnai is histologically divisible into anterior and posterior parts. In the anterior region the villi are taller and more abundant than in the posterior region, showing that absorption mainly takes place here.

The presence of an ileo-rectal sphincter in the rectum of fishes has been reported by many authors (Al-Hussaini, 1946; Thomas, 1975 and Sis et al., 1979). They have observed that among the fishes they studied those with the sphincter had a short intestine. In $H$. krishnai the rectal region is provided with an ileo-rectal sphincter formed by the telescoping of the rectum into the intestine. This helps the fish to retain the already digested food in the intestine for a longer duration, till the absorption is complete. This is needed since the gut of $H$. krishnai is comparatively short (RLG - 0.4).

In the subterranean waters, plant life is not possible. The mud of the well bottom is poor in organic matter. So the only available food in this particular habitat is animal matter such as insects and other small crustaceans. So the subterranean habitat made the fish to take in animal matter and the alimentary canal of the fish is modified to suit this carnivorous habit.

\section{ACKNOWLEDGEMENTS}

The first author is grateful to CSIR, New Delhi for the award of a fellowship during the tenure of which the work was carried out.

\section{REFERENCES}

AL-HUSSAINI, A.H. 1946. The anatomy and histology of the alimentary tract of the bottom feeder - Mulloides auriflamma (Forsk.). J. Morph., 78: 121-153.

AGARWAL, V.P. and UMA SHARMA. 1966. Morpho-histological studies on the digestive tract of Mystus vittatus (Bloch).

Proc. natn. Acad. Sci. India, 36 (B): 411-456.

BARRINGTON, E.J.W. 1957. The alimentary canal and digestion. In "The Physiology of Fishes", (M.E. Brown, ed.). Vol. I, Academic Press, N.Y., 109-154. 
CHITRAY, B.B. 1965. The anatomy and histology of Puntius sarana (Ham.) with a note on feeding habits. Ichthyologia, 4: 53-63.

DAS, S.M. and S.K. MOITRA. 1955. Feeding habits of freshwater fishes of the Uttar Pradesh. Curr. Sci., 24: 4-18.

DHARMARAJAN, M. 1936. The anatomy and histology of the alimentary system of Otolithus ruber (Bl. Schn.). Proc. Indian Sci. Congr. 23rd, (Abstract).

GIRGIS, S. 1952. The bucco-pharyngeal feeding mechanism in an herbivorous, bottom-feeding cyprinoid, Labeo horie (Cuvier). J. Morph., 90: 281-315.

JACOBSHAGEN, E. 1913. Untersuchungen uber das Darmsystem der Fische and Dipnoer II. Jena Z. Naturw. 49: 373-810.

KAPOOR, B.G. 1953. The anatomy and histology of the alimentary canal in relation to its feeding habits of a siluroid fish Wallago attu (Bl. \& Schn.). J. zool. Soc. India, 5: 191-210.

- 1957. The anatomy and histology of the digestive tract of a cyprinoid fish, Catla catla (Ham.). Ann. Mus. Stor. nat. Genova, 70: 100-115.

LAL, M.B. 1968. Studies on the anatomy and histology of the alimentary canal of a carp, Tor putitora (Ham.) Proc. natn. Acad. Sci. India, 38: 127-136.

MAHADEVAN, S. 1950. The digestive system of Caranx djedab (Forsk.) and Trichiurus haumela (Forsk.). J. Madras Univ., 20: 25-48.

MEHROTRA, B.K. and S.S. KHANNA. 1969. Histo-morphology of the oesophagus and the stomach in some Indian teleosts with inference of their adaptational features. Zool. Beitr., 15: 375-391.

MOHSIN, S.M. 1941. A preliminary study on the morphology and histology of an air breathing fish, Anabas testudineus (Bl.) Proc. 28th Indian Sci. Congr., (Abstract).

- 1946. Histology of alimentary tract of a freshwater goby, Glossogobius giuris (Ham.). Proc. 33rd Indian Sci. Congr., (Abstract).

- 1962. Comparative morphology and histology of the alimentary canals in certain groups of Indian teleosts. Acta Zool. Stockh., 43: 79-130.

MOITRA, S.K. and M.L. BHOWMIK. 1967. Functional histology of the alimentary canal of the young Catla catla (Ham.) an omnivorous surface feeding fish of Indian freshwaters. Vest. Csl. Spol. zool., 31: 41-50.

MOITRA, S.K. and A.K. RAY. 1977. Morphology of the alimentary canal of an Indian freshwater perch, Colisa fasciata (Bloch) in relation to food and feeding habits. Anat. Anz., 141: 37-58.

MOITRA, S.K. and G.M. SINHA. 1971. Studies on the morpho-histology of the alimentary canal of a carp, Chagunius chagunio (Hamilton) with reference to the nature of taste buds and mucous cells. J. Inland Fish. Soc. India, 3: 44-56.

- 1972. The structure, distribution and probable function of taste buds and mucous cells in the alimentary tract of a freshwater major carp, Cirrhina mrigala (Ham.). J. Inland Fish. Soc., India, 4: 103-114.

MOOKERJEE, H.K. and D.N. GANGULY. 1952. Modification of the facial structures in the major carps of India in relation to their feeding habits. Anat. Anz., 98: 137-147.

PASHA, S.M. KAMAL. 1964. The anatomy and histology of the alimentary canal of an omnivorous fish, Mystus (Macrones) gulio (Ham.) Proc. Indian Acad. Sci., 59: 211-221.

PILLAY, T.V.R. 1953. Studies on the food, feeding habits and alimentary tract of the grey mullet, Mugil tade Forskal. Proc. natn. Inst. Sci. India, 19: 777-827.

SARBAHI, D.S. 1939. The alimentary canal of Labeo rohita (Ham). J. Asiat. Soc. Beng., 5: 87-116.

- 1951. Studies on the digestive tracts and the digestive enzymes of gold 
fish, Carassius auratus L. and the largemouth blackbass, Micropterus salmoides. Biol. Bull., 100: 244-257.

SINHA, G.M. and S.K. MOITRA. 1972. The comparative histology of the alimentary canal of Cirrhina rebu (Ham.) during the different stages of life-history in relation to food and feeding habits. Proc. 59th India Sci Congr. Part III, 464.

- 1975. Morpho-histology of the intestine in a freshwater major carp, Cirrhinus mrigala (Ham.) during the different life-history stages in relation to food and feeding habits. Anat. Anz., 137. 395-407.

- 1976. Structure, distribution and probable functions of 'end-buds' and 'mucous' cells in the buccopharyngeal region of four Indian freshwater major carps. J. Inland Fish. Soc., 7: 7-15.

SIS, R.F., P.J. IVES, D.M. JONES, D.M. LEWIS and W.W. HAENSLY. 1979. The microscopic anatomy of the oesophagus, stomach and intestine of the channel catfish. Ictalurus punctatus. J. Fish. Biol., 14: 79-186.

SUYEHIRO, Y. 1942. A study on the digestive system and feeding habits of fish. Jap. J. Zool., 10: 1-303.

THOMAS, P.P. 1975. Studies on the alimentary canal of Etroplus maculatus (Bloch). Bull. Dept. Marine Sci., Univ. Cochin, 7: 511-521.

VANAJAKSHI, T.P. 1938. Histology of the digestive tract of Saccobranchus fossilis and Macrones vittatus. Proc. Indian Acad. Sci., 7: 61-80. 